\title{
Stephanie Rohlfing-Dijoux
}

Université Paris Ouest Nanterre La Défense e-mail: dijoux.stephanie@orange.fr phone: +33014097 7364

DOI: $10.15290 / \mathrm{mhi} .2014 .13 .01 .07$

\section{Internationalization of Studies and Research - The Example of the Integrated French-German Law Curriculum at the University Paris Ouest Nanterre La Défense}

\author{
SUMMARY \\ Internationalization of Studies and Research - \\ The Example of the Integrated French-German Law Curriculum \\ at the University Paris Ouest Nanterre La Défense
}

Legal experts of international firms need a sound knowledge of national law systems and international law. In view of decision-making processes that assume a global perspective rather than the perspective of one centralized headquarters, they need appropriate human resources from many countries with employees who can combine legal, technical and economic advice. The requirement is a knowledge of methods to cope with new and unknown law systems. The role of the law faculty is to put students in the position to understand what law is, to train their abilities of being able to identify legal problems and find appropriate solutions to them. Faculties should aim at equipping their students with the tools and methods that will later put them in a position to achieve these goals.

Law faculties have to adapt law curriculums to the requirements of education of international legal experts. For this reason, the teaching of intercultural skills and judicial terminology in foreign languages takes an important part in the law curriculum. These special programs begin at an early stage of law studies.

Key words: Internationalization of studies, Europeanization of research, integrated curriculums, legal education, multiligualism

Słowa kluczowe: umiędzynarodowienie studiów, europeizacja badań naukowych, zintegrowany program studiów, edukacja prawnicza, wielojęzyczność

\section{Introduction}

The University Paris Ouest Nanterre La Défense (UPON), formerly the University Paris X, was built in 1963 in the West of Paris on a large 65-acre 
campus near the Défense business district. The initial stone laying ceremony took place on $5^{\text {th }}$ November 1963 and inauguration of the first buildings occurred on $2^{\text {nd }}$ November 1964. The law faculty was launched in 1967. In 2014 the Nanterre University celebrated its 50th anniversary.

Today it hosts nearly 32,000 students, 2,000 teaching staff and 700 administrative support staff. The University is made up of 9 Colleges known as U.F.R. (Unités de Formation et de Recherche), 2 Training Institutes, 6 Doctoral Schools and 2 Research Institutes.

Since 1989 the Nanterre University has offered a dual curriculum which combines studies of French law with another European law system (common law, German law, Spanish law, Italien law and Russian law). All of theses curriculums involve close collaboration with partner universities in all respective countries. At first such collaboration was mainly based on the exchange of students and teachers but with the passage of time it has developed into a much wider scientific alliance.

\section{The issue of national and international law}

Even if companies operate mainly in a global economy without borders, law is basically a national affair. Each law system and legislation is based on and linked to a nation. International law without linkage to a specific country is almost nonexistent and thus legal experts need to know the domestic interpretation and enforcement of international law.

International private law manifests itself in national law with differences from country to country. It aims at regulating conflicts between national laws. This is achieved by an agreement on the national law that is to be applied in the event of resolving a dispute at an international level ${ }^{1}$.

International public law regulates relations between states and international organisations. International public law manifests itself in the law of nations, in international agreements or conventions, and in bilateral, plurilateral or multilateral treaties.

International trade rules are necessary because national governments alone connot cope with the challenges presented by economic globalization. The protection of important societal values such as public health, environmental standards, consumer safety, cultural identity, and minimum labour standards are no longer a purely national matter, but ever more so a matter with significant international ramifications. In the field of international law students need specilized knowledge of international human rights, of international labour

1 F. Moneger, Droit international privé, Paris 2001, $\mathrm{n}^{\circ} 6$. 
law based on the standards of the International Labour Organisation, of international criminal law defined by the International Court of Justice and of international economic law including the International Trade Law and the World Trade Organisation (WIPO, GATS and EPO), the World Bank and the International Monetary Fund. Another subject is International Commercial Law with the law of international commercial contracts ${ }^{2}$.

Knowledge of international law is an important requirement for legal experts in international operating companies, but by itself this is not sufficient. They also need a rigourous knowledge of national law and an understanding of social issues. Attempts to ensure the protection of these values on the national level alone are ineffective. Domestic regulatory measures regarding product safety, health, environmental protection and labour standards, differ from country to country and they constitute a significant constraint on trade. For these reasons legal experts need knowledge of national laws, in particular knowledge of environmental law, consumer law, right to information, intellectual property law, competition and labour law.

\section{The role of a law faculty in teaching legal advisors in the international field}

In order to comprehensively educate students in the field of international law, faculties need to combine studies of national law, comparative law, international law, legal translation, linguistics and cultural skills. Law practitioners in the international field also need an understandings of economics. Therefore, the curriculum essentially needs to bring law and economics together.The aim is to promote multilinguism, multiculturalism, and performance in order to reach a standard of professionel excellence. The question therefore, is how to teach law in this era of globalization and how to motivate students to undertake international and comparative law studies?

Future international law practitioners need to study comparative law for different reasons. With regard to tax law, for example, the principles of taxation differ from one country to another. Knowledge of these different rules allows to locate a company in an other economic zone or country. In terms of globalization, legal practitioners need to know comparative national tax law but also bilateral and multilateral tax treaties, the aim being to avoid double taxation and find legal and profitable solutions to other tax related issues.

For direct foreign investment legal experts need awareness of the regulations of foreign exchange and investments as well as of the laws of financial services and markets. The liberalization of international trade and direct for-

2 H. Kenfack, Droit du commerce international, Dalloz 2002 Paris, p. 5. 
eign investment over the last fifty years has, in most developed countries, gradually lowered barriers for foreign trade and allowed free movement of capital. But in different parts of the world, the degree of liberalization is different and national rules for direct foreign investement and capital movement still exist.

Legal advisors need knowledge of international economic organizations, of international trade financing, of banking and insurance law, of the legal aspects of finance and alternative dispute resolution, etc. Economic and monetary unions throughout the world (SADC - South African Developement Community, COMESA - Common Market for Eastern and Southern Africa, the EU) as well as multilateral and plurilateral trade agreements, are a matter of prime importance for strategy making and for business decisions.

However, since legislation changes over time, students need to learn methods and tools to deal with new rules and new law systems ${ }^{3}$. "Learning by doing" helps in adapting to such continuing changes: When students need to deal with two or more law systems while studying, they will also be able to multi-task in their professional practice.

The role of the law faculty is to put students in the position to understand what law is, to train their abilities of being able to identify legal problems and to find appropriate solutions. The role of a lawyer is to represent a client in the client's best interest and the role of a legal advisor is to find the best legal solutions for his or her corporate employer. Faculties should aim at equipping their students with the tools and methods that will later put them in the position to achieve these goals.

The challenge is to teach law students the comprehension of different law systems like common law and civil law as well as the knowledge of differents intercultural skills. For this aim we need to combine teaching of national law and all related interdisciplinary fields.

\section{The double diploma curriculum in french and german law at the university paris ouest nanterre la défense (upon)}

In the German-French law curriculum, students study the law systems of both France and Germany and in the two languages, simultaneously learning multilinguism, multiculturalism, law and economic understandings ${ }^{4}$.

3 S. Rohlfing-Dijoux, La méthode juridique en Franc et en Allemagne : différences et convergences, in S. Rohlfing-Dijoux, La transmission de terminologie et de concepts juridiques dans l'espace européen, Bern 2012, p. 47.

4 O. Seul, Les cursus binationaux - une étape vers l'harmonisation des études en Europe, in: O. Seul, B. Zielinski, U. Dupuye, De la communication interculturelle dans les relations franco-allemandes: institutions - Enseignement et formation professionnelle - Entreprises, 2003, p. 285. 
The University Paris Ouest Nanterre (UPON) offers intergrated law degree courses in German and French $\mathrm{Law}^{5}$ and in inter-disciplinary fields such as the language and civilisation of Germany. This dual curriculum is run in partnership with the German University of Potsdam (close to Berlin) ${ }^{6}$. It is a program controlled by and with the financial support of the German/French University College ${ }^{7}$.

In this curriculum students concurrently study German and French law such that they can compare both law systems better. German Law lectures are conducted by invited professors as well as by local professors and lecturers. A significant number of faculty members in Paris are not French. This is part of a deliberate strategy of internationalization. Every year, more than twenty visiting professors from German universities conduct lectures on German law at UPON.

\section{Bachelor Level}

Students of the German/French law curriculum are selected on entry to the curriculum based on a language test. They can begin their studies in Potsdam, if they possess sufficient kowledge of the German language. Otherwise they can begin the first year of their bachelor studies in Nanterre. In both cases students stay for two years in the country where they begin their studies. In the third year, students from Potsdam come back to Nanterre together with the German students from the programme. Likewise students who spend the two first years in Nanterre will go to Germany in the third year.

After the 3 years of bachelor studies, all students will have spent at least one or two years at the partnering university. The failure rate is only about $10 \%$.

The particular points in the curriculum are the interdisciplinary courses in language (German/French and English) and civilization.

\section{Language courses}

Language courses are mandatory in the curriculum. Terminology is a matter of common concern for legal professionals as legal concepts, which must be explained as precisely as possible, can only be expressed by use of recognised legalese. Often, law concepts and their attendant legalese are unique

5 Other double diploma curriculums are run at UPON with French/Italien law (University of Bologna); French/Spanish law (University Charlos III of Madrid); French/Commun law (University Essex); French/Russian law (State law academy Moscau).

6 J. Gruber, Der deutsch-französische Studiengang der Universitäten Paris Ouest Nanterre La Défense und Potsdam, ZEuP 2013, p. 205.

7 www.dfh-ufa.org; Common curriculum with Potsdam since 1989 - fifth with the University of Mainz (with support of the German/French University College) and since 1994 with the University of Potsdam. 
to a national law system and cannot readily be translated into another language. To enable students to understand law concepts in another language they need to be explained in the context of known law systems and existing law concepts ${ }^{8}$. For the translation of law-related texts, a jurisdictional culture and knowledge of law concepts of the other legal system are necessary. For this reason, juridicial translation needs to use tools of comparative law and is based more on adaptation and explanation than on translation itself. Courses in legal translation resemble lecturers in comparative law.

These language courses take place in the form of laboratory classes and tutorials. The subject of these classes are translations of judgements, bills, regulations, other law-related texts and legal terminologie.

\subsubsection{Courses in civilization}

Lectures on the political and social system of Germany, its legal history and history of political institutions are part of the law curriculum. Future employees working with German partners or clients need a sound knowledge of German culture in order to understand their German counterparts and avoid misunderstandings.

\subsubsection{Interculturalism}

Intercultural topics are incorporated in interdisciplinary language courses and civilization courses. For legal advisors acquiring knowledge of intercultural skills is mandatory. With globalization national economies are becoming more and more integrated into a borderless global economy. Employees of multinational entreprises have to work with subsidiaries in different countries and with business partners throughout the world. More than ever before people from different countries, regions and cultures of the world now collaborate and compete with with each other. In order to fulfill the challenges of globalization, legal experts need also to be competent in intercultural skills?.

\section{Masters Level - three language option}

In the first year of their masters studies, students can again choose to either go to Potsdam or stay in Nanterre.

All students from the Masters 2 billingue des droits de l'Europe must spend

8 S. Rohlfing-Dijoux, La transposition des concepts juridiques originaux dans un autre système de droit : traduction ou adaptation? in Cahier d'études germaniques 2009, $\mathrm{N}^{\circ} 56$; Traduire, adapter transposer, p. 183.

9 A. Thomas, E.U. Klinast, S. Schroll-Machl, Handbuch Interkulturelle Kommunikation, BD.I Grundlagen und Praxisfelder, Kulturen und interkulturelle Berufstätigkeit, Göttingen 2005. 
the second year of their Masters abroad: they can go back to Potsdam or another German university or a university in a third country. UPON offers the possibility of three-language studies. Students can spend one or two semesters in a third country with a third language and law system.

These students normally receive an Erasmus scolarship and they will study within the Erasmus framework without the need for a special study programme. They can just pick up courses in the language and the law of the host country. Most of these students are interested in going to English speaking countries, but there are also many students who want to spend a year or a semester in another European country or in some other part of the world.

In 2010/2011 students of the Masters curriculum have been in England, Canada (Montreal Mc Gill) and in Spain (sevilla). In 2009/2010 they have been in Canada (Edmonton, Vancouver) and Hungary; in 2011/2012 in South Africa, Spain (Sevilla), Turkey and Canada; in 2012/2013 in Canada, Spain (Sevilla) and in 2013/2014 students will be in China (Remington University) and Norway.

At the end of the year the students write a Masters thesis in French with a summary in German. The three-language option is subject to a diploma supplement. This Masters programme is limited to 26 students each year.

For this three-language study curriculum UPON needs to collaborate closely together with European and other partner universities in the world. Therefore, UPON has established academic as well as research partnerships and collaborations, signing MoU's with universities abroad. In 2013 the Nanterre University signed two new MoU's with the University of Mauritius and with Guajadar National Law University (GNLU) in India for the exchange of students and teachers.

\section{PhD Track}

Since 2011 UPON has been testing a new curriculum for PhD Students: The $\mathrm{PhD}$ Track. This PhD track consists of five years of studies, which includes two years of Masters studies plus three years of doctorate studies. Beginning with the first year of masters studies, students participating in the PhD Track are encouraged to find a theme for a $\mathrm{PhD}$ thesis and to start with preparations for that thesis. They benefit from methodological lecturers and from pedagogical supervision. Guest professors from German universities and universities from other countries organize seminars and lectures in their field of research and specialization. These guest lectures provide students with an update on current law problems and evolutions in the field, thereby providing a continuous source of inspiration for finding research themes for a future doctorate thesis project. The PhD Track is linked with the Diplôme Universitaire of the 
International Law college ${ }^{10}$ de $1^{\prime} \mathrm{UPON}$. The seminars and guest lectures are mutualized with this Law school.

\section{The European network of Erasmus coordinators}

The European Erasmus network Paris Ouest Nanterre has been established since the mid-90s.. The coordinators of the Erasmus/Socrates programmes and those responsible for international relationships - members of this network meet once a year to evaluate their activities in terms of student and teacher mobility as well as their scientific cooperation and, of course, to reflect upon how to further invigorate and broaden all these exchanges in the process of European higher education, the so-called "Bologna Process"11.

The choice of locations for the yearly meetings is intended to signal European ambitions within the framework of the progressive European process of integration: Each year a new partner university in a new partner country hosts the meeting, thus furthering development of the network.

Without the close cooperation of the teaching staff and administrative personnel, international cooperation would simply not function: both have different, but reciprocally supplementary competencies. Jointly their complementary functions are required for the successful internationalization of teaching and research. Therefore, the partner universities not only send members of their teaching staff, but also frequently members of the administrative staff to further benefit international relations.

Since the annual meeting in 2000 we have encouraged a strengthening of the transmission of knowledge at the research level within the framework of the network: thanks to the panel sessions for PhD students and colloquia regarding the questions of European integration, particularly regarding the process of the legal harmonization in countries of the European Union, this has been largely achieved. This network has been developed within the ERASMUS programmes contributing to the Internationalization of study and research by:

- the integration of study programmes between partner Universities (of special importance being the integrated French-German study program that has been established between Nanterre and Potsdam since 1989);

- introducing a jointly supervised thesis procedures by partner universities, which would result in a doctorate qualification being mutually awarded by two universities ${ }^{12}$;

10 Collège international de droit, http://ufr-dsp.u-paris10.fr/ufr-de-droit-et-science-politique-dsp/college-international-de-droit.

11 Compare www.droit-fr-all-paris-ouest.fr.

12 F. Limbach, Die französische Co-tutelle de thèse, ZEuP 2000, p. 702 ff.; F. Limbach, A. Honsdorf, 
- organization of a round of conferences on the major trends of legal harmonization in the EU member states;

- organization of European Summer Schools uniting teachers, doctorate students and masters students ${ }^{13}$.

\section{Europeanization and internationalization of research}

French-German cooperation in the field of research and education and the bilateral teaching structures implemented have for the past several years been open to third countries.

The University Paris Ouest Nanterre La Défense and its German partner the University of Potsdam developed tri-national research projects in comparative law and opened the German-French law studies to third countries (example the three language options). The aim is to promote the multilingualism, the multiculturalism and professional performance of our students.

The summer university in Vilnius took place for the 11th time in 2014. This summer law school is organized with panel sessions and workshops with important student participation. Lecturers, PhD students, under-graduate students and law professionals meet on a yearly basis in order to exchange information on the developments of law in their respective countries and the harmonization of law in the European Union. The question of European identity was raised after refusal of the referendum of Maastrich in the Netherlands and France in 2005. Papers of the summer school of 2008 on the subject of solidarity in the European Union were published in $2012^{14}$. In 2013 the topic was the "harmonization of law on national identity", and in 2014 the topic of the $11^{\text {th }}$ summer school will be "Europe: Diversity without discrimination."

The success of these summer schools illustrates the importance of Europeanization of studies and research. But these efforts are not limited to European territory.

In 2011 UPON, in association with its partner university Potsdam and with the support of the Franco-German University (DFH/UFA), initiated a joint, trinational European summer university in Minsk, capital of Byelorussia, which is not a member state of the European Union. In this way European law discussion is opened to the community of independent European countries, the so called "European law space". The summer school in Minsk took place in June 2013 for the $3^{\text {rd }}$ time on the subject of "The most important tasks of the

Neues zum Verfahren der Cotutelle de thèse, ZeuP 2007, p. 692; J. Gruber, Das deutsch-französische Doppelpromotionsverfahren, (" cotutelle de thèse »), JURA 2011, p. 319.

13 Compare www.droit-fr-all-paris-ouest.fr.

14 O. Seul, T. Davulis, La solidarité dans l'Union Européenne, Bern 2012. 
state today: the funding of the welfare state, the promotion of the economy, the guarantee of security, the legal protection and freedom of citizens".

These summer universities have become a source of inspiration for other universities and countries. Lima will organize one this coming September, the first German-French-Peruvian Summer University on the subject of State of law and democracy.

In 2013 UPON organized with its partner university Potsdam the first German-French-Tunisian summer university in Tunis. This law school was held in three sessions of two days each (in March, April and September). Tunisian universities are keenly interested in cooperation with European and especially German universities.

Most of these summer law schools are mainly based on French-German cooperation including the universities of third countries. They also have the institutional and financial support of DFH/UFA.

This concept of internationalization of studies and research by common summer universities is becoming more and more important. The summer law schools take an important part in the process of internationalization of studies and research. They favour the transfer of knowledge by using comparative law and are an integrated part of our German-French law studies which have existed since 1989.

The summer law schools give young researchers, PhD Students, and masters students the opportunity to create an international network with participants from other countries, who often come from eastern European countries, like Lithuania, Estonia, Latvia, Romania, Hungary, Poland, Byelorussia, Turkey, etc.

These initiatives demonstrate that UPON has designed and implemented its own visions and its own strategy concerning the Internationalization of studies and research. This has been noticed by government ministries and other institutions as being a source of inspiration for new projects in the field of transnational cooperation.

Current new projects aim at developing an integrated thesis programme ${ }^{15}$ with the Universities of Potsdam and Dresden in the framework and with the financial support of DFH/UFA. For young researchers and $\mathrm{PhD}$ Students this will offer an integrated German-French research programme for a jointly supervised thesis with one of the German partner universities. This programme will be opened also to $\mathrm{PhD}$ students of faculties of finance, management and economics to stimulate interdisciplinary research. 


\section{Bibliographie}

Cornu G., Linguistique juridique, Paris 1990.

Gruber J., Der deutsch-französische Studiengang der Universitäten Paris Ouest Nanterre La Défense und Potsdam, ZEuP 2013.

Gruber J., Das deutsch-französische Doppelpromotionsverfahren (« cotutelle de thèse »), JURA 2011.

Kenfack H., Droit du commerce international, Dalloz Paris 2002.

Limbach F., Die französische Co-tutelle de thèse, ZEuP 2000.

Limbach F., Honsdorf A., Neues zum Verfahren der Cotutelle de thèse, ZEuP 2007.

Moneger F., Droit international privé, Paris 2001.

Rohlfing-Dijoux S., La méthode juridique en Franc et en Allemagne : différences et convergences, in : S. Rohlfing-Dijoux, La transmission de terminologie et de concepts juridiques dans l'espace européen, Bern 2012.

Rohlfing-Dijoux S., La transposition des concepts juridiques originaux dans un autre système de droit : traduction ou adaptation?, in : Cahier d'études germaniques, Traduire, adapter, transposer 2009, N 56.

Seul O., Les cursus binationaux - une étape vers l'harmonisation des études en Europe, in: Seul O., Zielinski B., Dupuye U., De la communication interculturelle dans les relations franco-allemandes: institutions - Enseignement et formation professionnelle - Entreprises 2003.

Seul O., Davulis T., La solidarité dans l'Union Européenne, Bern 2012.

Thomas, A. Klinast, E. U., Schroll-Machl, S., Handbuch Interkulturelle Kommunikation, BD.I Grundlagen und Praxisfelder, Kulturen und interkulturelle Berufstätigkeit, Göttingen 2005. 